\title{
Cervical Clear Cell Adenocarcinoma
}

National Cancer Institute

\section{Source}

National Cancer Institute. Cervical Clear Cell Adenocarcinoma. NCI Thesaurus. Code C6344.

A rare morphologic variant of cervical adenocarcinoma composed of clear and hobnail cells. It is associated with in utero exposure to diethylstilbestrol (DES). 